\title{
某紡績工場における農村勤労婦人の産業疲労に 関する研究
}

\author{
吉田暢夫, 中川昭 生, 牧野由美子*, 山根 洋 右 ${ }^{*}$
}

\section{はじめに}

近年, 山陰の農村地帯にも多くの誘致工場が進出し, そこで働く農村婦人も増加している。これら農村勤労 婦人は劣悪な労㗢条件下での工場勤務に加え，いぜん として出勤前・帰宅後あるいは日曜・祝祭日には農業 労働に従事している者も多く, 労働の過重による疲労 蓄積や健康障害が深刻化していることが推測される。 したがって，農村勤労婦人の生活実態および疲労状 況・健康状態を把握し, 地域保健活動および産業衛生 活動の両面から, 総合的健康管理体制を確立してゆく ことが重要となっている。

われわれは, このよらな農村勤労婦人の疲労状態を 把握し，その防止対策を樹立することを目的とし，山 陰の某紡績工場に勤務する農村勤労婦人を対象として 調査をおこなった。

\section{I. 調 查 方 法}

\section{1. 対象工場の概要}

対象とした工場は昭和 43 年に島根県益田市郊外に設 立された，資本金 4 億 3 千 6 百万円，従業員数男性 75 人, 女性 164 人, 合計 239 人の紡績工場である。

作業工程は機械化されており，「サンド」(原料綿の

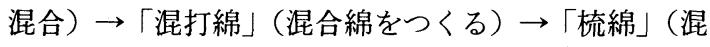

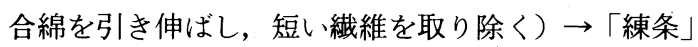

（綿の纎維を平行に伸ばして均一な 1 本の糸をつく る) $\rightarrow$ 「粗紡」 $\rightarrow$ 「精紡」 $\rightarrow$ 「捲系」 $\rightarrow$ 「荷造り」と なっている。

作業内容としては 1 人当り紡績機 $3 \sim 4$ 台を受け持 ち，機械管理をしながら終了した製品を次の工程へ移 す立作業，および同じく立作業で「玉揚げ」と呼ばれ る $1 \mathrm{~kg}$ 前後の粗紡を機械からはずして上方へ持ち上 げる, 1 作業動作 3 秒程度の上肢反復作業が中心であ る。したがって, 下肢・上肢・腰部の筋負担が大きい。

\footnotetext{
* 島根医科大学環境保健医学教室
} 受付：昭和 56 年 10 月 1 日
1 棟約 1 万 $\mathrm{m}^{2}$ の作業場は空がなく, 非常に綿ぼこ りが多いにもかかわらず, 空調・換気装置も不十分で ある。照度は85〜300ルックス, 室温は一年中 $28 \sim 30^{\circ} \mathrm{C}$ に調整され, 湿度は平均 $62 \sim 65 \%$, 騒音は $80 \sim 97$ ホン である。

勤務時間は 3 組 3 交替制がしかれ, 第一組が $5: 00$ $\sim 13: 30$, 第二組が $13: 30 \sim 22: 00$, 第三組が $22: 00$ 〜 $5: 30$ となって拈り，第三組は男性の又就業する。 休噁時間は食事時間が途中に45分間あるだけで， 1 連 続作業時間は 3 時間 5 時間 15 分と長い。年次休暇は 7 日, 生理休暇は月 2 回, どちらも有給で認められて いる。

健康管理体制は保健室に看護婦が 1 名配置され，1 週間に 3 回, 嘱託産業医による出張診療が実施されて いる。衛生管理者は 4 名, 安全衛生委員会は毎月 1 回 定例化され, 工場内外巡視結果に基づく改善策等につ いて討議されている。定期健康診断結果は毎回全員に 通知されるほか, 年 2 回の職場健康教育が成人病対策 を中心に実施されている。

\section{2. 調査方法}

1 ). 調査対象

就労女子労働者164名中, 事務関係および調査当日の 欠勤者を除いた138名を対象として，健康診断・疲労調 査および生活調査をおこなった。また，任意に抽出し た 35 才以上の女子労㗢者 30 名に対して, フリッカー検 査, 自律神経機能検査および尿中クレアチニン測定を おこなった。

調査対象者の年齢階層は40才代がもっとも多く73名 (52.9\%)，ついで10才代・20才代34名（18.1\%)，30 才代19名（10.9\%)，50才代12名（8.7\%）である。

\section{2). 調査内容および調査期間}

(1). 生活アンケート調查: 独自に作成した 9 項目より なる生活アンケート調査にて,「家の職業および農業規 模」「本人の農作業従事状況」「休養のとり方」「勤務理 由および勤務前の状況」などについて調査した。配布 
は健診 3 日前におこない健診時に回収した。回収率は 138名（94.5\%）であった。

また，労働時間・睡眠時間などの生活時間調査は健 診時の聞き取り調查によりおこなった。

(2). 疲労調査: 日本産業衛生協会・産業疲労研究会の 疲労自覚症状調査表をもとに新しく提案された疲労自 覚症状調査表 1$)$, 拈よび若月 2) が提起した農夫症調査 表を使用し，工場での作業終了直後に自己記入法にて おこなった。

また，任意に抽出した早出勤務の女性30名について， 早朝作業につく前（午前 4 時 20 分から 5 時までの間） と作業後（午後 1 時 30 分から 2 時までの間）の 2 回, フリッカー検査および尿中クレアチニン測定をおこ なった。

フリッカー値は 5 回測定し, 最小值と最大値を除い た 3 回の值を平均してその值とした。尿中クレアチ= ンはワコーのクレアチニンテスト用キットを使用し, 日立100-60型分光光度計にて測定した。

さらに, 同じく作業前後の 2 回, 自律神経機能検査 として冷水負荷試験をおこない，そのうち20名につい ては皮膚温を,残り10名については血圧值を測定した。

冷水温度は被験者の苦痛を考慮して $7^{\circ} \mathrm{C} て ゙ 1$ 分間と し，皮膚温は左手第二指掌を宝工業デシタル温度計 HD111-6 型にて30秒でとに3分間，血圧は右手にて冷 水中および引き揚げ後 1 分間ごとに 3 分間測定した。 (3). 健康診断：問診, 検尿 (蛋白, 糖, ウロビリノー ゲン, 潜血), 血圧測定, 貧血検査 (血色素量, ヘマト クリット值), 肝機能検查 (GPT, ALP, ZTT), 血清脂 質検査（総コレステロール，中性脂肪， HDL-コレス テロール), 内科診察に加えて, 全員に心電図および眼 底検查をおこなった。なお，検査方法は採血後血清を 分離し $4{ }^{\circ} \mathrm{C}$ 保存, 48 時間以内に GPT はライトマ ン・フランケル法, ALPは Kind-King 法, ZTTは硫 酸亜鉛混濁法, 総コレステロールおよび中性脂肪は酵 素法, HDL-コレステロールはデキストラン硫酸・マ グネシウム法によっておこなった。

健康診断・生活調査および疲労自覚症調査は昭和56 年 3 月 22 ・23日に打こなった。また, フリッカー検查, 尿中クレアチニン測定, 自律神経機能検査（血圧およ び皮膚温の冷水反応試験）は 9 月21日に扣こなった。

\section{II. 調 查 結 果}

\section{1. 農村勤労婦人の生活背景}

工場勤務に出はじめた理由としてもっとも多いの は，「家計が苦しくなったから」(40.2\%) で，次いで 「子供の手がかからなくなった」(22.1\%) となってい
る。50才代では減反政策および機械化によって「農業 がひまになった」(27.3\%) といら回答も多いが, 農業 を完全にやめて工場勤務に出はじめたものはほとんど いない。

対象者の $ち$, 第一種兼業農家 $12.6 \%$, 第二種兼業 農家 $40.5 \%$ となっているが, これらの 4 割は耕地面積 $50 \mathrm{a}$ 末満の零細農家である。農家婦人のらち, 日常的

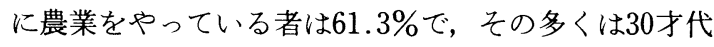
以上の年龄層である。また，農作業をおこなら時間帯 としては,「日曜・祝祭日」83.9\%,「勤務から㷌って から」 $44.6 \%$,「早朝, 勤務に出る前」 $12.5 \%$ となって おり,「日曜農業」あるいは「片手間農業」の状況を示 している（表-1）。

表 1 ．農作業への従事状況

\begin{tabular}{|c|c|c|c|c|c|}
\hline 項目 & $\begin{array}{l}10 \cdot 20 \\
\text { 才代 }\end{array}$ & 30才代 & 40才代 & 50才代 & 全体 \\
\hline $\begin{array}{l}\text { 恒常的 } \\
\text { 剚 }\end{array}$ & - & $\begin{array}{c}4 \\
(21.0)\end{array}$ & $\begin{array}{c}29 \\
(39.7)\end{array}$ & $\begin{array}{c}5 \\
(41.7)\end{array}$ & $\begin{array}{c}38 \\
(27.5)\end{array}$ \\
\hline $\begin{array}{l}\text { 季節的 } \\
\text { 従 事 }\end{array}$ & $\begin{array}{c}1 \\
(2.9)\end{array}$ & $\begin{array}{c}3 \\
(15.8)\end{array}$ & $\begin{array}{c}14 \\
(19.2)\end{array}$ & $\begin{array}{c}1 \\
(8.3)\end{array}$ & $\begin{array}{c}19 \\
((3.8)\end{array}$ \\
\hline 従事せず & $\begin{array}{c}17 \\
(50.0)\end{array}$ & $\begin{array}{c}9 \\
(47.4)\end{array}$ & $\begin{array}{c}24 \\
(32.9)\end{array}$ & $\begin{array}{c}6 \\
(50.0)\end{array}$ & $\begin{array}{c}56 \\
(40.6)\end{array}$ \\
\hline 不 明 & $\begin{array}{c}16 \\
(47.1)\end{array}$ & $\begin{array}{c}3 \\
(15.8)\end{array}$ & $\begin{array}{c}6 \\
(8.2)\end{array}$ & - & $\begin{array}{c}25 \\
(18.1)\end{array}$ \\
\hline 計 & $\begin{array}{c}34 \\
(100.0)\end{array}$ & $\begin{array}{c}19 \\
(100.0)\end{array}$ & $\begin{array}{c}73 \\
(100.0)\end{array}$ & $\begin{array}{c}12 \\
(100.0)\end{array}$ & $\begin{array}{c}138 \\
(100.0)\end{array}$ \\
\hline
\end{tabular}

注：従事せずには，非農家婦人を含む

一方, 1 日平均労働時間は 8.1 時間, 平均睡眠時間は 6.7時間で, 年代が高くなるほど睡眠時間が短く, 労働 時間が長くなっている。とくに，恒常的に農業にたず さわっている者は労働時間が最高16時間, 平均8.6時 間, 睡眠時間が最低4.5時間, 平均6.3時間とかなり身 体を酷使している。

休日の過ごし方は「家事・育児」51.6\%，「農作業」 $30.6 \%$ で，とくに 30 才代以上では，この 2 項目で $90 \%$ 以上を占め,「趣味・レクリェーション」など, 積極的 に休養をとっているものは全体の $6.5 \%$ にすきない。

\section{2 . 健康診断結果}

疾病としてもっとも多いのは疲労との密接な関連が 指摘されている貧血症 ${ }^{3)}$ で24名 (19.8\%), そのらち, 治療または精査を要する者が10人 (41.7\%) であった。 平均血色素量は $13.1 \mathrm{~g} / \mathrm{d} \ell$, 平均へマトクリット值 40.3 $\%$ で, 年代別には, 40 才代が同 $12.8 \mathrm{~g} / \mathrm{d} \ell, 35.9 \%$ と最 
低を示している。

高血圧症は 7 名 $(4.9 \%)$, 境界域高血圧は 12 名 8.5 \%)であり，心電図に左室肥大や虚血性变化が出現し た者は25名 (18.0\%)，眼底所見異常率は24名 (16.9\%) であった。ただし，心電図所見で明らかな異常は 1 名 (0.7\%) で, 眼底異常所見の多くは動脈硬化性変化で あった。

また，作業姿勢等に由来すると思われる職業性頸肩 腕障害 ${ }^{4)}$, 腰痛症 5 )の疑いをもつ者が19名(13.8\%) み られた。

血清脂質では総コレステロールは高値者 5 名(3.6 \%) に対して低值者 8名（5.8\%）とむしろ低值者が 多く, 逆に中性脂肪は高値者が12名 (8.5\%) と多かっ た。HDLーコレステロールは平均值 $57.1 \pm 12.3 \mathrm{mg} / \mathrm{d} \ell$ で低值者は 3 名 (2.1\%) と少なかった。年代別には総 コレステロール, 中性脂肪, HDL-コレステロールとも に差異は認められないが，動脈硬化指数（総コレステ
ロールーHDL-コレステロール/HDL-コレステロー ル）は30才代の 2.2 から 40 才代には2.5へと急に高く なっている。

農家類型別には, 平均血圧値には差がみられないが, 負血出現率は第一種兼業農家で $35.7 \%$ と高くなってい る。また，血清脂質では，総コレステロールおよび中 性脂肪は大差ないが，HDL-コレステロールは第一種 兼業農家が $53.1 \mathrm{mg} / \mathrm{d} \ell$ と, 非農家の $58.4 \mathrm{mg} / \mathrm{d} \ell$, 第 二種兼業農家の $58.6 \mathrm{mg} / \mathrm{d} \ell$ に比し低值を示した。

生活時間との関係では, 労働時間が10時間以上では 貧血出現率が $36.4 \%$ で，10時間未満の $16.7 \%$ に比し高 率である。また，睡眠時間が短いほど貧血出現率が高 く, 7 時間未満では $29.9 \%, 7 \sim 7.9$ 時間が $8.6 \%, 8$ 時間以上が $3.2 \%$ となっている。高血圧および境界域高 血圧出現率は, 睡眠時間 7 時間未満 $16.4 \%, 7 \sim 7.9$ 時 間 $11.4 \%, 8$ 時間以上 $6.4 \%$ と, 睡眠時間 8 時間以上で 低い傾向を示した（表 $-2 \cdot 3$ )。

表 2. 農作業従事状況・休日の過ごし方と健康状態

\begin{tabular}{|c|c|c|c|c|c|c|c|}
\hline \multirow{2}{*}{ 項 } & \multicolumn{3}{|c|}{ 農作業従事状況 } & \multicolumn{4}{|c|}{ 休日の過ごし方 } \\
\hline & 恒常的従事 & 季節的従事 & 従事せず & 消極的休養 & スポーツ・趣味 & 農 業 & 家事·育児 \\
\hline 人 数 & 38 & 19 & 56 & 28 & 5 & 37 & 51 \\
\hline 平均血色素量 & $12.5 \pm 2.0$ & $13.0 \pm 1.7$ & $13.7 \pm 1.5$ & $13.7 \pm 1.2$ & $14.6 \pm 1.1$ & $12.7 \pm 2.1$ & $12.9 \pm 1.8$ \\
\hline 平均へマトクリット值 （\%) & $38.8 \pm 4.7$ & $40.0 \pm 4.2$ & $41.0 \pm 3.5$ & $42.1 \pm 3.0$ & $43.2 \pm 3.3$ & $39.4 \pm 4.9$ & $39.6 \pm 4.2$ \\
\hline 平均血圧収縮期 $(\mathrm{mm} \mathrm{Hg})$ & $122.3 \pm 16.3$ & $122.1 \pm 11.4$ & $121.2 \pm 19.0$ & $123.6 \pm 20.3$ & $116.6 \pm 14.2$ & $124.1 \pm 16.1$ & $119.9 \pm 13.8$ \\
\hline " 拡張期 $(\mathrm{mm} \mathrm{Hg})$ & $73.8 \pm 10.6$ & $75.6 \pm 8.4$ & $74.5 \pm 10.7$ & $74.3 \pm 12.3$ & $72.8 \pm 13.3$ & $75.5 \pm 10.1$ & $73.3 \pm 9.2$ \\
\hline 貧血出現率 & 26.3 & 26.3 & 7.1 & 10.7 & 0.0 & 21.6 & 21.5 \\
\hline 高血圧出現率 & 5.3 & 0.0 & 7.1 & 14.3 & 0.0 & 5.4 & 0.0 \\
\hline $\begin{array}{c}\text { 境界域高血厓 } \\
\text { 出現 }\end{array}$ & 13.2 & 5.3 & 8.9 & 3.6 & 0.0 & 13.5 & 7.8 \\
\hline
\end{tabular}

表 3. 労働時間・睡眠時間と健康状態

\begin{tabular}{|c|c|c|c|c|c|c|c|}
\hline \multirow{2}{*}{ 項 } & \multicolumn{3}{|c|}{ 労 働 時 間 } & \multicolumn{4}{|c|}{ 睡 眠 時 間 } \\
\hline & $\sim 8$ & $8 \sim 10$ & $10 \sim$ & $\sim 5.9$ & $6.0 \sim 6.9$ & $7.0 \sim 7.9$ & $8.0 \sim$ \\
\hline 平均血色素量 $\quad(\mathrm{g} / \mathrm{dl})$ & $13.2 \pm 1.7$ & $13.4 \pm 2.2$ & $11.6 \pm 3.4$ & $12.4 \pm 2.4$ & $12.4 \pm 1.8$ & $13.7 \pm 1.3$ & $13.8 \pm 1.2$ \\
\hline 平均ヘマトクリット值 （\%) & $40.5 \pm 4.1$ & $41.0 \pm 5.2$ & $38.5 \pm 4.9$ & $38.4 \pm 5.4$ & $39.1 \pm 4.2$ & $41.8 \pm 3.6$ & $42.0 \pm 3.0$ \\
\hline 平均血圧収縮期 $(\mathrm{mm} \mathrm{Hg})$ & $120.7 \pm 16.5$ & $131.4 \pm 18.4$ & $120.0 \pm 13.9$ & $122.6 \pm 13.0$ & $122.9 \pm 17.3$ & $120.5 \pm 15.7$ & $117.4 \pm 17.2$ \\
\hline " 拡張期 $(\mathrm{mm} \mathrm{Hg})$ & $74.4 \pm 10.5$ & $81.2 \pm 14.2$ & $73.8 \pm 7.0$ & $77.3 \pm 6.9$ & $74.6 \pm 10.3$ & $74.9 \pm 11.5$ & $71.5 \pm 10.5$ \\
\hline 貧血出現率 & 16.5 & 20.0 & 36.4 & 22.2 & 32.7 & 8.6 & 3.2 \\
\hline 高血圧出現率 & 5.2 & 20.0 & 0.0 & 0.0 & 8.2 & 5.7 & 3.2 \\
\hline $\begin{array}{l}\text { 境界域高血压 } \\
\text { 出現率 }\end{array}$ & 7.8 & 0.0 & 9.1 & 11.1 & 10.2 & 5.7 & 3.2 \\
\hline
\end{tabular}




\section{3. 疲労調査}

1). 疲労自覚症調査および農夫症調査

疲労自覚症調査による訴え率は総合で $26.3 \%$ と高 $<$ ，とくにI 群「一般的症状」II群「精神的症状」III 群「局所的な身体症状と自律神経症状」として成分 別に分析すると, II 群の精神的症状がきわめて高く なっている。この傾向は40才代・50才代においてとく
に強く,これらの年代では, I > II > III（II-dominant 型）の完全な「夜勤型・精神作業型」を示した。項目 別にもっとも多いのは「肩がこる」(64.6\%)，次いで 「横になりたい」(61.9\%)，「㸚むい」(54.9\%)，「目が 疲れる」(53.1\%) で，上位 2 項目は若い年代でも高率 を示した（表一 4$)$ 。

労働時間が農業労働も含めて10時間以上におよぶ長

表 4 . 疲労症 状調 査結果

\begin{tabular}{|c|c|c|c|c|c|c|}
\hline & 項 & 10,20 才代 & 30 才代 & 40 才代 & 50 才代 & 全体 \\
\hline & 1. 頭がおもい & 5.9 & 26.3 & 32.9 & 50.0 & 26.8 \\
\hline & 2. 全身がだるい & 17.6 & 36.8 & 37.0 & 41.7 & 32.6 \\
\hline & 3. 足がだるい & 26.5 & 47.4 & 49.3 & 50.0 & 43.5 \\
\hline \multirow[t]{3}{*}{. $\mathrm{I}$} & 4.あくびがでる & 44.1 & 57.9 & 49.3 & 33.3 & 47.8 \\
\hline & 5.頭がぼんやりする & 11.8 & 26.3 & 20.5 & 25.0 & 19.6 \\
\hline & 6. ねむい & 35.3 & 68.4 & 52.1 & 58.3 & 50.7 \\
\hline \multirow[t]{8}{*}{ 群 } & 7. 目が疲れる & 23.5 & 36.8 & 60.3 & 66.7 & 48.6 \\
\hline & 8.動作がぎこちない & 11.8 & 10.5 & 17.8 & 25.0 & 15.9 \\
\hline & 9. 足もとがたよりない & 5.9 & - & 11.0 & 8.3 & 8.0 \\
\hline & 10.横になりたい & 52.9 & 47.4 & 65.8 & 58.3 & 59.4 \\
\hline & $\begin{array}{llll}\text { I } & \text { 平 均 }\end{array}$ & 23.5 & 35.8 & 39.6 & 41.7 & 35.3 \\
\hline & 11. 考えがまとまらない & 11.8 & 5.3 & 24.7 & 41.7 & 20.3 \\
\hline & 12. 話をするのがいやになる & 11.8 & 5.3 & 17.8 & 16.7 & 14.5 \\
\hline & 13. いらいらする & 11.8 & 31.6 & 27.4 & 25.0 & 23.9 \\
\hline \multirow{3}{*}{ II } & 14. 気がちる & 8.8 & 10.5 & 16.4 & 16.7 & 13.8 \\
\hline & 15. 物事に熱心になれない & 11.8 & 15.8 & 38.4 & 25.0 & 27.5 \\
\hline & 16. ちょっとしたことが思い出せない & 11.8 & 31.6 & 42.5 & 41.7 & 33.3 \\
\hline \multirow{8}{*}{ 群 } & 17. するととにまちがいが多くなる & 5.9 & 5.3 & 21.9 & 41.7 & 17.4 \\
\hline & 18. 物事が気にかかる & 17.6 & 26.3 & 60.3 & 33.3 & 42.8 \\
\hline & 19. きちんとしていられない & 2.9 & 10.5 & 24.7 & 16.7 & 16.7 \\
\hline & 20. 根気がなくなる & 8.9 & 15.8 & 28.8 & 50.0 & 23.9 \\
\hline & $\begin{array}{llll}\text { II } & \text { の 平 均 } \\
\end{array}$ & 10.3 & 15.8 & 30.3 & 30.8 & 23.4 \\
\hline & 21．頭が痛い & 11.8 & 21.1 & 32.9 & 25.0 & 25.4 \\
\hline & 22. 肩がこる & 50.0 & 47.4 & 69.9 & 83.3 & 63.0 \\
\hline & 23. 腰が痛い & 11.8 & 31.6 & 41.1 & 50.0 & 33.3 \\
\hline \multirow{3}{*}{ III. } & 24. 息苦しい & 2.9 & 5.3 & 5.5 & 16.7 & 5.8 \\
\hline & 25. ロがかわく & 11.8 & 21.1 & 21.9 & 25.0 & 19.6 \\
\hline & 26. 声がかすれる & 2.9 & 5.3 & 5.5 & 8.3 & 5.1 \\
\hline \multirow{5}{*}{ 群 } & 27. めまいがする & 2.9 & 15.8 & 16.4 & 33.3 & 14.5 \\
\hline & 28. まぶたや筋肉がピクピクする & 17.6 & 5.3 & 32.9 & 33.3 & 25.4 \\
\hline & 29. 手足がふるえる & - & 5.3 & 5.5 & - & 3.6 \\
\hline & 30. 気分が悪い & 5.9 & 15.8 & 5.5 & 8.3 & 7.2 \\
\hline & III の 平 均 & 11.8 & 17.4 & 23.7 & 28.3 & 20.3 \\
\hline & Total & 15.2 & 23.0 & 31.2 & 33.6 & 26.3 \\
\hline
\end{tabular}


時間労働群の疲労自覚症訴克率は, 総合で $39.1 \%$ と高 率を示し，とくにII群の精神的症状の訴えが高い。睡 眠時間との関係では， 6 時間未満の睡眠しかとれてい ない婦人は, 訴交率 $37.2 \%$ と高いが，とくに，睡眠時 間に関係なく全体的に高率を示す「肩がこる」「横にな りたい」といった項目以外にも，「全身がだるい」「足 がだるい」「あくびがでる」「目が疲れる」といった「ね むけとだるさ」を示す項目が $60 \%$ 以上の訴交を率し た（表 -5 )。

また, 農家類型別には, 農家は I 群 $34.1 \%$, II 群 $24.7 \%$, III群 $18.1 \%$, 非農家の同 $34.2 \%, 18.3 \%$, $20.2 \%$ に比してII 群の訴え率が強く I > II > IIIの II -dominant 型を示した。同様に, 恒常的に農作業にも 従事している婦人と工場勤務のみの婦人の間では, I 群, III群には差がみられないが, II群の精神的疲労は
高い訴え率を示した。

また，休養のとり方でみると，日曜・祝祭日も「家 事・育児」や「農作業」に追われている婦人は訴え率 も高く, I >II >IIIの II-dominant 型を示した（表-6）。

慢性疲労の指標として用いた農夫症調査でも, 農夫 症平均点数は 3.5 点, 同発生率 $12.5 \%, 3$ 点以上の農夫 症疑いまで含めれば50\%以上と高率を示した。項目と してもっとも多いのはやはり「肩こり」で，時々ある ものもあわせて $71.3 \%$, 次いで,「腰痛」が $47.8 \%$ とな っている。

また, 疲労自覚症調査における傾向と同じく, 長時 間労働群, 短時間睡眠群, 恒常的農業従事群, 日曜 祝祭日も家事・育児や農作業で追われる群などでは， 農夫症平均点数, 同発生率ともに高く, 慢性疲労状態 にあることを示している。

表 5 . 労働時間・睡眠時間亡疲労

\begin{tabular}{|c|c|c|c|c|c|c|c|c|c|}
\hline \multirow{2}{*}{ 項 } & \multirow{2}{*}{ 目 } & \multicolumn{3}{|c|}{ 労 働 時 間 } & \multicolumn{4}{|c|}{ 睡 眠 時 間 } & \multirow{2}{*}{ 全 体 } \\
\hline & & $\sim 8$ & $8 \sim 10$ & $10 \sim$ & $\sim 5.9$ & $6 . \overline{0 \sim 6.9}$ & $7.0 \sim 7.9$ & $8.0 \sim$ & \\
\hline \multirow[t]{2}{*}{ 人 数 } & (人) & 112 & 5 & 11 & 18 & 50 & 37 & 32 & 137 \\
\hline & I & 33.0 & 32.0 & 50.0 & 47.2 & 37.8 & 35.9 & 24.5 & 35.6 \\
\hline \multirow{3}{*}{$\begin{array}{l}\text { 疲労自覚症 } \\
\text { 訴え率 (\%) }\end{array}$} & II & 21.7 & 14.0 & 40.0 & 33.3 & 27.1 & 26.5 & 11.4 & 24.2 \\
\hline & III & $18 .{ }^{\prime}$ & 26.0 & 27.2 & 31.1 & 22.4 & 20.3 & 10.7 & 20.6 \\
\hline & Total & 24.3 & 24.0 & 39.1 & 37.2 & 29.1 & 27.5 & 15.5 & 26.8 \\
\hline \multicolumn{2}{|c|}{ 農夫症平均点数 （点） } & 3.2 & 3.6 & 5.5 & 5.3 & 3.8 & 3.0 & 1.9 & 3.4 \\
\hline \multicolumn{2}{|c|}{ 農夫症 発生率 } & 10.7 & 0.0 & 36.4 & 27.8 & 16.7 & 6.1 & 3.4 & 12.3 \\
\hline
\end{tabular}

表 6 . 農作業従事状況・休日の過でし方と疲労

\begin{tabular}{|c|c|c|c|c|c|c|c|c|}
\hline \multirow{2}{*}{ 項 } & \multirow{2}{*}{ 目 } & \multicolumn{3}{|c|}{ 農作業従事状況 } & \multicolumn{4}{|c|}{ 休日の過ごし方 } \\
\hline & & 恒常的従事 & 季節的従事 & 従事せず & 消極的休養 & スポーツ・趣味 & 農業 & 家事·育児 \\
\hline \multirow[t]{2}{*}{ 人 数 } & （人） & 38 & 19 & 56 & 28 & 5 & 37 & 51 \\
\hline & I & 38.4 & 32.1 & 39.1 & 25.5 & 22.0 & 37.4 & 41.4 \\
\hline \multirow{3}{*}{$\begin{array}{l}\text { 疲労自覚症 } \\
\text { 訴え率 (\%) }\end{array}$} & II & 27.9 & 28.4 & 21.8 & 11.3 & 10.0 & 25.9 & 27.6 \\
\hline & III & 21.8 & 18.4 & 21.8 & 14.1 & 12.0 & 19.7 & 24.5 \\
\hline & Total & 29.4 & 26.3 & 27.6 & 17.0 & 14.7 & 27.7 & 31.2 \\
\hline \multirow{2}{*}{$\begin{array}{l}\text { 農夫症平均点数 } \\
\text { 農夫症発生率 }\end{array}$} & (点) & 3.4 & 3.3 & 3.7 & 1.9 & 3.0 & 3.5 & 4.2 \\
\hline & $(\%)$ & 12.8 & 17.6 & 14.5 & 0.0 & 20.0 & 15.4 & 14.3 \\
\hline 平均睡眠時間 & $(\mathrm{h})$ & $6.3 \pm 0.8$ & $6.6 \pm 0.5$ & $6.9 \pm 1.1$ & $8.0 \pm 0.5$ & $7.9 \pm 0.1$ & $8.5 \pm 1.1$ & $7.9 \pm 0.6$ \\
\hline 平均労働時間 & $(\mathrm{h})$ & $8.6 \pm 1.1$ & $8.0 \pm 0.3$ & $7.9 \pm 0.7$ & $7.5 \pm 0.8$ & $6.8 \pm 1.3$ & $6.3 \pm 0.7$ & $6.5 \pm 1.0$ \\
\hline
\end{tabular}

2). 他覚的疲労検查

フリッカー值は作業前 $31.3 \pm 3.5 \mathrm{c} / \mathrm{s}$, 作業後 $34.4 \pm$ $3.6 \mathrm{c} / \mathrm{s}$ で，作業後の方に $3.1 \mathrm{c} / \mathrm{s}$ の増加がみられた。 作業後に低下した者は 4 名（13.3\%）であった。 冷水負荷による皮膚温の変動では, 作業後の方が冷
水によく反応し, 回復状況も良好であった（表 -7 )。 同じく冷水負荷による血圧值ではあまり変動がみら れず, $7^{\circ} \mathrm{C}$ の冷水に 1 分間とい5負荷では, とくに作 業後には有効なストレスになりにくいものと思われる (表 -8 )。 
表 7. 冷水負荷試験（皮膚温）

\begin{tabular}{|c|c|c|c|c|}
\hline \multirow{2}{*}{ 経過時間 } & \multicolumn{2}{|c|}{ 作業前 } & \multicolumn{2}{|c|}{ 作業後 } \\
\hline & 皮虞温 & 回復率 & 皮膚温 & 回復率 \\
\hline 負荷前 & $25.5^{\circ}$ & $100.0^{\%}$ & $32.7^{\circ}$ & $100.0^{\%}$ \\
\hline 30 秒後 & 18.2 & 71.4 & 22.8 & 69.7 \\
\hline $60 "$ & 18.0 & 70.7 & 24.0 & 73.3 \\
\hline $90 "$ & 18.4 & 72.1 & 25.7 & 79.0 \\
\hline $120 "$ & 18.7 & 73.5 & 27.7 & 84.6 \\
\hline $150 "$ & 19.1 & 75.1 & 29.1 & 88.6 \\
\hline $180 "$ & 19.4 & 76.2 & 30.0 & 91.3 \\
\hline
\end{tabular}

尿中クレアチニンは正常値 $(0.7 \sim 1.2 \mathrm{~g} / \mathrm{d} \ell)$ 以上に 增加している者が, 作業前 6 名 (20.0\%), 作業後11名 (36.7\%) であった。また，平均値は，作業前 $1.01 \pm 0.31$ $\mathrm{g} / \mathrm{d} \ell$, 作業後 $1.18 \pm 0.51 \mathrm{~g} / \mathrm{d} \ell$ とどちらも正常值範用 内であるが，作業後に若干高い值を示した。

\section{3). 疲労の健康への影響}

疲労自覚症調査の訴え項目数によって疲労程度を I 〜 IVの 4 群に分類してみると, 疲労程度が高い群ほど 平均年路が高く, 労働時間が長くなり睡眠時間が短い。 また, 農夫症点数も高い。この疲労程度別に健康診断
表 8. 冷水負荷試験（血圧） 単位 : $\mathrm{mmHg}$

\begin{tabular}{c|cc|cc}
\hline \multirow{2}{*}{ 経過時間 } & \multicolumn{2}{|c|}{ 収縮期血圧 } & \multicolumn{2}{c}{ 拡張期血圧 } \\
& 作業前 & 作業後 & 作業前 & 作業後 \\
\hline \multirow{2}{*}{ 負荷前 } & 123.2 & 126.7 & 83.5 & 81.8 \\
& $(100.0)$ & $(100.0)$ & $(100.0)$ & $(100.0)$ \\
負荷中 & 130.5 & 123.2 & 83.5 & 80.6 \\
& $(105.9)$ & $(97.2)$ & $(100.0)$ & $(98.5)$ \\
30 秒後 & 127.6 & 123.0 & 83.2 & 81.1 \\
& $(103.6)$ & $((97.1)$ & $(99.6)$ & $(99.1)$ \\
$90 "$ & 124.6 & 116.7 & 84.9 & 80.8 \\
& $(101.1)$ & $(92.1)$ & $(101.7)$ & $(98.8)$ \\
$120 "$ & 123.1 & 116.3 & 83.8 & 80.5 \\
& $(99.9)$ & $(91.8)$ & $(100.5)$ & $(98.4)$
\end{tabular}

注：（）内は負荷前を100とした場合の比率

結果を比較すると, 血液性状は $I$ 群を除けば疲労が少 ない注ど良好であり, 貧血出現率は疲労度の低いI 群 で低率である。平均血圧値は収縮期血圧, 拡張期血圧 ともにあまり差がみられないが，I群において若干低 く, 高血圧および境界域高血圧出現率も低率である。 血清脂質への疲労の影響はみられず, 心電図および眼 底では, 疲労のもっとも少ないI 群で所見が少なかっ た（表-9）。

表 9 . 疲労程度別健康調查結果

$(\overline{\mathrm{x}} \pm \mathrm{SD})$

\begin{tabular}{|c|c|c|c|c|c|}
\hline 項 & & I & II & III & IV \\
\hline 人 数 & （人） & 40 & 29 & 21 & 48 \\
\hline 平均年 令 & （才） & $31.7 \pm 11.6$ & $39.5 \pm 9.3$ & $41.1 \pm 8.9$ & $42.6 \pm 8.0$ \\
\hline 労 働 時 間 & $(\mathrm{h})$ & $7.9 \pm 0.5$ & $8.1 \pm 0.7$ & $8.2 \pm 0.9$ & $8.2 \pm 0.9$ \\
\hline 睡 眠 時 間 & $(\mathrm{h})$ & $7.2 \pm 1.0$ & $6.7 \pm 0.8$ & $6.2 \pm 1.1$ & $6.5 \pm 1.0$ \\
\hline 農夫症平均点数 & (点) & 1.3 & 2.5 & 4.6 & 5.4 \\
\hline ヘモグロビン量 & $(\mathrm{g} / \mathrm{dl})$ & $13.6 \pm 1.4$ & $13.0 \pm 1.6$ & $12.3 \pm 1.9$ & $13.1 \pm 1.9$ \\
\hline ヘマトクリット值 & $(\%)$ & $41.6 \pm 3.8$ & $40.0 \pm 3.7$ & $38.8 \pm 4.4$ & $40.2 \pm 4.5$ \\
\hline 総コレステロール & $(\mathrm{mg} / \mathrm{dl})$ & $189.7 \pm 37.2$ & $187.8 \pm 25.5$ & $186.1 \pm 36.1$ & $197.2 \pm 32.0$ \\
\hline 中性脂肪 & $(\mathrm{mg} / \mathrm{dl})$ & $105.2 \pm 26.7$ & $108.6 \pm 34.6$ & $102.2 \pm 33.1$ & $105.3 \pm 31.2$ \\
\hline HDL-コレステロール & $(\mathrm{mg} / \mathrm{dl})$ & $57.6 \pm 13.6$ & $57.3 \pm 11.5$ & $57.6 \pm 10.7$ & $57.3 \pm 12.5$ \\
\hline 動脈硬化指数 & & $2.4 \pm 0.8$ & $2.4 \pm 0.6$ & $2.3 \pm 0.8$ & $2.5 \pm 0.7$ \\
\hline 最 高 血圧 & $(\mathrm{mmHg})$ & $116.6 \pm 13.0$ & $128.7 \pm 19.4$ & $120.0 \pm 24.0$ & $120.6 \pm 16.0$ \\
\hline 最低血圧 & $(\mathrm{mmHg})$ & $71.1 \pm 9.5$ & $78.8 \pm 11.4$ & $75.1 \pm 9.1$ & $74.5 \pm 10.0$ \\
\hline 貧血出現率 & $(\%)$ & $3(7.5)$ & $5(17.9)$ & $7(33.3)$ & $9(18.8)$ \\
\hline 高血圧出現率 & $(\%)$ & $0(0.0)$ & $3(10.7)$ & $1(4.8)$ & $3(6.3)$ \\
\hline 境界域高血圧出現率 & $(\%)$ & $2(5.0)$ & $4(14.3)$ & $2(9.5)$ & $4(8.3)$ \\
\hline 心電図変化 & $(\%)$ & 5.0 & 24.1 & 9.5 & 12.5 \\
\hline 眼 底 異 常 & $(\%)$ & 5.0 & 10.3 & 4.8 & 22.9 \\
\hline $\begin{array}{r}※ \text { 疲労程度は疲労 } \\
\text { I }: 0 \sim 3 \text { 項 } \\
\text { III }: 7 \sim 9 \text { 項 }\end{array}$ & $\begin{array}{l}\text { 症状調 } \\
\text { II } \quad \text { 目 }\end{array}$ & $\begin{array}{l}\text { え項目による } \\
6 \text { 項目 } \\
\text { 頁目以上 }\end{array}$ & \multicolumn{3}{|c|}{$\begin{array}{l}\text { ※ 心電図変化とは左室肥大及び虚血性変化を示す } \\
\text { ※ 動脈硬化指数 }=\frac{\text { 総コレステロール-HDLコレステロール }}{\text { HDLコレステロール }}\end{array}$} \\
\hline
\end{tabular}




\section{III. 考察}

近年, 婦人労働者数は増加の一途をたどり, 全国統 計で, 昭和 54 年には 1,310 万人, 労働者総数の $33.8 \%$ と これまでの最高を示している。島根県においても，婦 人労働者数は昭和 30 年の 23,066 人から 52 年 100,491 人 へと増加し，とくに製造業，サービス業，建設業，金 融保険業等の部門での増加がめだっている。年代別に は30才代，40才代が多く，35才以上が全体の54\%を占 めている。顀金面では，月間現金給与総額が，54年で 132, 804円, その男女間格差は男性の $55.8 \%$ となってい る。とくに, 単純作業へのパートタイム雇用, 日雇, 常勤ではあっても日給月給制の支払い形態が中高年齢 層の婦人を中心に増加している。

一方, 農村の都市化, 工業化のなかで，いわゆる「土

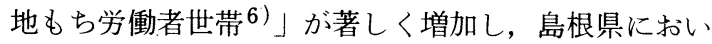
ても専従者のいない農家は，昭和 54 年で全体の $76.7 \%$ と「一家総兼業」時代を迎えている。とくに婦人の農業 就労人口は, 昭和 49 年の 79,400 人から, 54 年には 59,200 人へと減少し，そのらちの 46,800 人は雇用兼業者と なっている。農家婦人のらち, 農業のみに従事してい る婦人は $39.9 \%$ しなく, 多くの農家婦人が現金収入 を求めて, 農村誘致工場に勤務している（表-10）。

表10．農村婦人農業就労の動向

\begin{tabular}{|c|c|c|c|}
\hline 年 代 & 農家人口 & 農業就業人口 & $\begin{array}{c}\text { 基幹的 } \\
\text { 農業従事者 }\end{array}$ \\
\hline 昭和 49 & $148,480(100.0)$ & $79,400(100.0)$ & $54,090(100.0)$ \\
\hline 51 & $139,980 \quad(94.3)$ & 68,810 & $36,660 \quad(67.8)$ \\
\hline 52 & $133,740 \quad(90.1)$ & $65,270 \quad(82.2)$ & $34,700 \quad(64.2)$ \\
\hline 53 & $133,720 \quad(90.1)$ & $62,280 \quad(78.4)$ & $30,910 \quad(57.1)$ \\
\hline 54 & 132,790 & $59,200 \quad(74.6)$ & $27,400 \quad(50.7)$ \\
\hline
\end{tabular}

(1979年 島根農林水産統計年報)

最近, 80 年代の政府の重点方針として, 山陰農村地 帯の工業化が提起されており，農村婦人が工場勤務に つく傾向は，ますをす拍車をかけられるものと予想さ れる。

一方, 今回の調査において, 農村勤労婦人はかなり の疲労状態に陥っている。疲労自覚症の総合訴え率 $26.3 \%$ は, 吉竹 ${ }^{1)}$ が示している女子事務作業者の作業 後における訴交率 $20.1 \%$, さらに, 質問項目は若干異 なるが，労働省婦人少年室7)がおこなった中国地方農 外就労婦人疲労調査の訴光率 $20.0 \%$, および, 横田 ${ }^{8)}$ が佐賀県南西部でおこなった農民の疲労調查結果
$20.4 \%$ より高率を示した。農夫症平均点数も, 西村 9 ) らが報告している秋田県の某子供服縫製工場勤務農村 婦人の 2.7 点, 同じくスピーカ製造工場勤務農村婦人の 3.3点, われわれ ${ }^{10)}$ の島根県農村地域における1.7 3.3 点より高い。

また，疲労の内容としては，肩こり，腰痛を中心と した局所筋疲労と, 疲労自覚症II群の訴㐬に示され る強い精神疲労が特徵的である。井上 ${ }^{11)}$ は, 農村工場 の婦人労働者の労働は, 軽労働だが労働密度が高く, なかには危険有害業務も少なくないことを指摘してい るが，今回のわれわれの対象工場においても自由動作 のできない立位での機械管理作業に加え, 長い 1 連続 作業時間と少ない休覟時間は, 強い産業疲労をもたら している。加えて, 機械の騒音, 綿ぼこりがひどいに もかかわらず，不十分な換気，機械に囲まれた 1 人作 業環境が，強い精神的疲労をも促進していると考えら れる。

フリッカー検査においては，むしろ作業前の方が 低い結果が得られたが, 大島总) はこらした結果が出現 する理由に, 睡眠不足により疲労回復が十分でないこ とをあげている。今回の検査においても，全員 3 時 30 分までに起床しており, 検查時間が 4 時 20 分から 5 時 までの早朝時であったこと，および被験者が慢性的な 睡眠不足におちいっていることなどが，低い值になっ たことに大きく関係しているものと思われる。皮膚温 および血圧の冷水負荷試験においても同様の結果であ り, むしろ作業前に, 自律神経機能低下の傾向がらか がわれた。これらの結果から，交替制勤務形態で働く 農村勤労婦人は, 早出のときには, 前日の疲労も十分 に回復することなく早朝に起床し, 完全な覚醒状態に いたらないまま作業に従事しているものと考えられ る。逆に, 遅出勤務のときには帰宅が拈そく, 就寝時 間が夜中になり，平均睡眠時間（恒常的農業従事者の 場合)が 6.3 時間と短いことからも推測されるように, 農家主婦の立場上，また住居状態からも，遅くまでゆっ くり休んでいるわけにはいかない。こいった交替制 勤務形態が，労働者に睡眠不足をもたらし，健康障害 をひきおこしていることは各種調査によって明らかに されている13)。とりわけ農村婦人は，こうした状況の 中で慢性的な睡眠不足におおいっており，それが，と くに精神疲労を中心とした慢性疲労状態を促進してい る。睡眠不足の影響は，睡眠時間 6 時間未満の婦人が， 8 時間以上の婦人に比し, 自覚症訴え率, 農夫症点数, 貧血出現率, 血色素量などの各項目でいずれも劣って いることからもみてとれる。この睡眠時間の確保は, 農村勤労婦人の疲労対策にとって重要な課題のひとつ 
であろら。

一方，われわれ(4) は，こうした農村勤労婦人の多く が，工場勤務による産業疲労に加えて, 農作業や家事 の負担による疲労も大きいことも指摘してきた。鈴木 15)らも，秋田県上郷地区の農業をしながら勤めるいわ ゆる「賃取り婦人」が，主に農業あるいは主に工場勤 務をしている婦人層よりも疲労状況が大きく, 慢性疲 労状態にあることを報告している。今回の調査におい ても, 農業労働も含めて労働時間が10時間以上におよ ぶ長時間労働の婦人が，とくに強い疲労状態におち いっていることが明らかとなった。

農村勤労婦人とりわけ中年層の婦人は, 経済的な理 由から勤務に出はじめたものの, いぜんとして農業や 家事の負担も大きく，勤務から帰っても身体を休ませ る状況にはない。休日も, 毎日の工場勤務のためにし わよせされている家事労働や農作業に追われ, 疲労回 復のゆとりなどない。くわえて, 前述したよらに交替 制勤務形態が，それを助長している。

また，家事時間の庄迫のために，食事も出来合いの ものなどを使った簡単なものにならざるを得ず, 低コ レステロール, 高中性脂肪などから推測される栄養の アンバランスも, これらの農村勤労婦人の疲労蓄積に 拍車をかけている。

こうした農村勤労婦人の強い慢性疲労状態は, 健康 面でも影響を与えている。血液性状は，季節変動 ${ }^{16)}$ の 面からみれば, 今回の調查時期 3 月は, 気候的にも農 作業の面からも良好な時期であるにもかかわらず, 悪 化している者がめだつ。貧血出現率は, 内田 ${ }^{17)}$ が報告 している, 秋田県以外の婦人の出現率10〜20\% と同程 度であった。とくに, 疲労程度の強い群ほど貧血出現 率も高く, 治療を要する強度貧血者も多い。高血圧出 現率も, 疲労程度の少ない群では低率であり, 心電図 および眼底所見の結果も含めて考えれば，将来にわた る成人病予防の一環として, 疲労対策が重要になって いるといえる。また，こらした疲労に加えて，その作 業姿勢や労働条件からくる職業性頸肩腕障害や職業性 腰痛の発生も注意する必要がある。

このよらに, 農村勤労婦人は, 工場勤務による産業 疲労に加之て, 農作業や家事を中心とした日常生活上 の様々な因子の相互関連の中で, 極度の過労状態にお ちいっていることが明らかにされた。したがって，農 村勤労婦人の健康管理対策として, 工場における労働 環境・労働条件の点検と改善, 職場健康管理の強化 ${ }^{18)}$, また, 地域での各種健康診断や健康教室への参加条件 の確保, とくに農業にも従事する農村勤労婦人に特徵 的な食生活や家事労働, および農業労働を含めた生活
点検と生活改善運動の展開が, 緊要な課題となってい る。とくに，従来別々にす寸められている，工場にお ける衛生委員会, 産業医, 衛生管理者, 産業保健婦に よる産業保健活動と, 保健婦を中心として, 保健所, 市町村, 農業改良普及所, 農協, 地区組織などの連携 による地域保健活動が，組織的に統一的に展開される 必要がある。

地方の振興を目的として誘致された工場が、「農家所 得の安定」とともに進行した農村の多忙化の中で，と りわけ中高年齢層の農村勤労婦人に慢性的な過労状態 をもたらし, 従来の健康管理活動に新たな対応をせ まっている。

\section{ま と め}

今回, 農村誘致工場に勤務する農村婦人の疲労状態 およびその要因を把握し，健康管理に役立たせるため に, 某工場の健康調查を実施し次のような結果を得た。 1 . 就労婦人の疲労状態は, 訴之率 $26.3 \%$, 農夫症平 均点数3.5点で, とくに恒常的に農業に従事している群 に有意に高い。フリッカーテスト, 自律神経機能検査, 尿中クレアチニン検査などにより，とくに交替制勤務 による精神的・肉体的負担の大きいことが推察され た。

2. 就労婦人の多くは, 強い慢性疲労状態にあり, 血 液性状も悪化し, 過労との関連が強い貧血症の頻度が もっとも高く, 軽度高血圧症への関与も推察される。

3. 疲労の内容としては, 頸, 肩, 腰を中心とした局 所筋疲労之精神疲労が特徵的であり, さらに, 職業性 頸肩腕障害や職業性腰痛を引き起こしている。交替制 勤務，作業姿勢，休㮃時間のとり方，作業環境などの 再検討と睡眠時間の確保, 疲労防止対策の樹立がのぞ まれる。

4. 中年層の農村勤労婦人は, 工場勤務による産業疲 労にくわえて，農作業や家事などが大きな負担となっ て, 過労状態に拍車をかけている。地域保健活動と産 業保健活動の統一的総合的展開が必要である。

$$
\text { 文献 }
$$

1 ) 吉竹 博: 産業疲労一自覚症状からのアプローチー, 労働科 学研究所, 川崎, 1978.

2 ) 若月俊一：農村医学, 勁草書房, 東京, 1971 .

3 ）野村 茂：生活之貧血，医米薬出版，東京， 1972.

4 ) 青山英康編: 頸肩腕障害, 労働基準調査会, 東京, 1979.

5 ) 青山英康, 明石謙共編：職業性腰痛, 労働基準調査会, 東京, 1980.

6 ) 井上和衛：零細兼業農家層の現状一いわゆる「土地もち労働 者」の実態一, 労働科学, 55(1), 13-40, 1979 .

7 ) 労働省婦人少年局 : 農家婦人の労働生活に関する意識調査, 
労働省婦人少年局, 東京, 1968.

8 ）横田良美：佐賀県南西地区農婦の居住地勢による体位, 血液 成分值, 疲労等の変化をめぐる疫学的検討, 日農医誌, 29(1), $1-21,1980$.

9 ) 西村 宏他：農村誘致工場就労婦人の生活および健康調査, 秋田農医誌, 26(1)，16-22，1979.

10）中川昭生他：山陰の農村地帯に打ける地域保健活動一地域 特性からみた健康実態と保健活動の課題一, 日農医誌, 29(6), 833-842, 1981.

11) 井上和衛：農村工業化に伴与低梖金労働力の創出一いわゆ る農村・納屋工場の労動条件一, 労働科学, 51(2), 69-89, 1975.
12) 大島正光：疲労の研究，同文書院，東京， 1980 .

13) 斉藤 一 : 交替制勤務, 労動科学研究所, 川崎, 1979.

14）中川昭生他：農村誘致工場における就労婦人の健康管理に 関する研究，日農医誌，30(2)，202-211，1981.

15）鈴木土身他：苝取り婦人の生活と健康について(第 2 報), 第 27回日農医学会講演集, 272-273，1978.

16）二塚 信他：農業従事者の血液諸性状の季節变動に関する 研究, 日本公衛誌, 27(5), 211-218, 1980.

17）内田昭夫：農村における血液性状よりみた健康の基礎的指 標に関する研究, 日農医誌, 27(5), 373-376, 1979.

18）望月清美子他：主婦の健康と健康管理に関寸る調査, 日本公 衛誌, 28(2), 81-90, 1981 .

\title{
Studies on the Industrial Fatigue of Workingwomen in a Factory in the Rural District
}

\author{
Nobuo Yoshida, Akio Nakagawa, Yumiko Makino \\ and Yosuke Yamane*
}

For the purpose to clarify the industrial fatigue and causative factors, the health examinations and the investigations of daily life were made to 138 workingwomen in a cotton-yarn factory in the rural district.

1) Comparing with other occupations, the fatigue in workingwomen was generally severe, especially in the middle-aged women who engaged in an agricultural labor besides the labor in the factory. As for the characteristics of their fatigue, the mental fatigue was more predominant than the physical fatigue. The results of Flicker test, autonomic nerve function test and urine creatinin test revealed the alternate shift working system in the factory was one of the causative factors which was responsible for the fatigue of the workingwomen.

2) The health examination revealed the high prevalence of anemia. The occurrence of the mild hypertension, the localized muscle fatigue and low back pain were also noteworthy. The investigations on the workingwomen's daily lives revealed that they engaged in an agricultural labor and households early in the morning or in the holidays, and worked for 8.6 hours in the average, and 16 hours in the maximum.

In addition to the industrial fatigue, the burdens of the agricultural labor and the households got worse the health conditions of the workingwomen. In the rural district it becomes very important to promote the comprehensive health care activities from the both sides of community health care system and occupational health care system.

* Department of Environmental Medicine, Shimane Medical University, Enya-cho 89, Izumo 693, Japan 